\title{
Mineral Composition and Effect of Biochar on Preweaning Reproductive and Growth Performance in Cavy (Cavia porcellus)
}

\author{
Christèle Kenne Nouboussi ${ }^{1}$, Fernand Tendonkeng', Nathalie Mweugang Ngouopo ${ }^{2}$, \\ Emile Miégoué1, Dieu-Nedort Djoufack ${ }^{1}$, Thierry Douglas Ndongo' ${ }^{1}$, Hamadou Ousmane ${ }^{1}$, \\ J. Gwladys Nkana Kontchiachou ${ }^{3}$, Cédric Brailly Kwayep Nyah', Mama Mouchili', \\ Pamo T. Etienne ${ }^{1}$
}

\author{
${ }^{1}$ Department of Animal Science, Faculty of Agronomy and Agricultural Sciences, University of Dschang, \\ Dschang, Cameroon \\ ${ }^{2}$ Faculty of Science, University of Ngaoundere, Ngaoundere, Cameroon \\ ${ }^{3}$ Institute of Agricultural Research for Development, Cameroon \\ Email: ftendonkeng@gmail.com
}

How to cite this paper: Nouboussi, C.K., Tendonkeng, F., Ngouopo, N.M., Miégoué, E., Djoufack, D.-N., Ndongo, T.D., Ousmane, H., Kontchiachou, J.G.N., Nyah, C.B.K., Mouchili, M. and Etienne, P.T. (2022) Mineral Composition and Effect of Biochar on Preweaning Reproductive and Growth Performance in Cavy (Cavia porcellus). Open Journal of Animal Sciences, 12, 145-157.

https://doi.org/10.4236/ojas.2022.121011

Received: September 14, 2021

Accepted: January 24, 2022

Published: January 27, 2022

Copyright $\odot 2022$ by author(s) and Scientific Research Publishing Inc. This work is licensed under the Creative Commons Attribution International License (CC BY 4.0).

http://creativecommons.org/licenses/by/4.0/

\begin{abstract}
In order to contribute to the improvement of the knowledge on the valorization of biochar as a feed additive in livestock, three biochar made from cassava peelings, bean tops and cocoa pods were manufactured. After analyzing their mineral composition, they were incorporated into rations at a rate of $0.8 \%$ in order to evaluate their effects on the performance of reproduction and pre-weaning growth in cavy (Cavia porcellus). The trials were conducted in the Research Unit of Animal Production and Nutrition (URPRONAN) of the University of Dschang, on 96 adult local breed cavy (from the first generation), including 80 females and 16 males aged 4 months and with an average weight of $400 \pm 0.25 \mathrm{~g}$. After 2 weeks of adaptation in the rearing boxes at the farm, the females were put in reproduction for a period of 31 days, the animals were divided into 04 batches of 20 females and 4 males. The animals in the control lot were fed a compound feed without biochar $(\mathrm{T})$ while the others were fed the compound feed containing $0.8 \%$ of cassava peel biochar (EM), $0.8 \%$ of bean tops biochar $(\mathrm{FH})$ and $0.8 \%$ of cocoa pod husks biochar (CC) respectively. The results of this study showed that the ash content $(26 \%)$ and macro-element concentration were higher in the bean husk charcoal compared to the other charcoals and the trace elements were more concentrated in the cassava peel charcoal. The best fertility rate $(87.5 \%)$ was obtained in animals receiving the ration containing organic cocoa pod charcoal. The highest abortion rate $(63.16 \%)$ was obtained in the batch of animals receiving the ration containing organic bean husk charcoal. Pre-weaning mortality rates were
\end{abstract}


comparable between the different rations. Piglet weights at birth were comparable between the different rations. At weaning, the highest average weight of the kids was recorded with the ration containing the organic bean charcoal $(197.25 \pm 46.9 \mathrm{~g})$. The highest ADG $(4.82 \pm 0.74 \mathrm{~g} / \mathrm{d})$ and TG $(101.25 \mathrm{~g})$ were recorded in the batch of animals receiving the $\mathrm{FH}$ ration. Thus, the incorporation of $0.8 \%$ of the powder of organic coals seems to have adverse effects on reproductive performance. On the other hand, these coals significantly improve the pre-weaning growth performance in cavy.

\section{Keywords}

Feed Additives, Biochar, Cavy, Ingestion, Reproduction, Pre-Weaning Growth

\section{Introduction}

In Africa in general and in Cameroon in particular, the imbalance observed between population growth and animal protein supply leads to increased malnutrition in most low-income families [1] [2] [3]. To fight against this scourge, the development and popularization of mini-breeding offer an alternative source of protein as much as they would contribute globally to the country's economy through the promotion of employment, trade and the preservation of biodiversity [4]. Thus, caviar farming, which does not require large initial investments, has the characteristics of an economically profitable mini-farm that can effectively participate in the fight for food security [5]. Despite its potential for meeting these needs, animal feed remains a real handicap for improving its production [5] since it represents more than $70 \%$ of production costs [6]. One of the possible solutions is the use of fodder legumes and other non-conventional protein sources whose nutritional value varies very little according to the seasons [3]. However, it has been observed that animals do not make the most of these forages, due to the poor health of their intestinal flora. Like ruminants, cavy harbor a large microbial population that ensures digestion and maintenance of microbial activity that requires a continuous supply of minerals to ensure proper functioning of the cecum. Yet, besides $\mathrm{C}, \mathrm{H}, \mathrm{O}, \mathrm{N}$, and $\mathrm{S}$, mineral elements $(\mathrm{Mg}$, $\mathrm{Ca}, \mathrm{K}$, and $\mathrm{P}$ ) are also present on the surfaces of biochar [7]. It is widely documented that, vitamins and minerals play an important role in animal growth and physiological functions, as well as reproductive performance [8]. Phosphorus and magnesium are essential skeletal components and are also involved in microbial fermentations in the rumen flora. Iron, present in hemoglobin, transports oxygen to tissue and muscle cells. It is essential for the production of adenosine triphosphate (ATP), the primary source of body energy. Selenium (Se) is necessary for growth, fertility of animals and prevention of various diseases [9]. Previous studies have shown positive effects of Canarium schweinfurthii Engl kernel charcoal used as growth promoters in birds [10]. The biochar modified 
feed has shown potential in controlling zoonotic pathogens in poultry [11]; reducing methane emissions in the rumen of cattle [12] and goat [13]. This charcoal could also bind feed toxins [10] that are either excreted in feces or degraded by certain organisms in the animal's gut microbiota. Based on previous results, the use of biochar in guinea pig diets could improve digestibility and therefore production performance. As very little information exists to this effect, the objective of the present study is to determine the mineral composition of cassava peelings, cocoa pod husks and bean tops biochar in order to evaluate their effects on the reproductive performance and pre-weaning growth of cavy.

\section{Material and Methods}

\subsection{Study Area}

This study was conducted between February and April 2021 in the Animal Production and Nutrition Research Unit (URPRONAN) of the University of Dschang. Located in the highlands of West Cameroon at an altitude of $1410 \mathrm{~m}$, at longitude East $09^{\circ} 5^{\prime}-10^{\circ} 06^{\prime}$ and latitude North $5^{\circ} 36^{\prime}-5^{\circ} 44^{\prime}$. This region receives between 1500 and $2000 \mathrm{~mm}$ of water per year, with temperatures ranging from $10^{\circ} \mathrm{C}$ to $25^{\circ} \mathrm{C}$. The climate is equatorial with a short dry season from mid-November to mid-March and a long rainy season from mid-March to mid-November.

\subsection{Animal Material and Housing}

For this trial, ninety-six (96) adult cavies were placed in a completely randomized setup, i.e., 80 females and 16 males of comparable weight (400 \pm 0.25$)$ distributed in four identical boxes of size $(2.5 \mathrm{~m} \times 0.5 \mathrm{~m})$, delimited by plated counter. Each box contained 4 males and 20 females conducted for 31 days. The floor of each lodge was lined with white wood shavings, which were renewed weekly to avoid the accumulation of feces and urine. Each lodge was equipped with a heating device, a plastic drinker and two wooden feeders and covered with a wire mesh to avoid the introduction of predators.

\subsection{Plant Material}

The plant material consisted of agricultural residues (cassava peelings of variety 8034; cocoa pod husks of variety forastero and bean tops of variety GLP) (Figure 1) harvested in the department of Menoua, for the manufacture of the different organic charcoals. These agricultural residues were chosen because of their accessibility and local availability.

\subsection{Processing of the Different Biochar}

The biochar used was obtained by slow pyrolysis of three plant residues that were chosen because of their accessibility and local availability. The different biochar obtained were crushed and sieved with a $2 \mathrm{~mm}$ mesh sieve before being incorporated at $0.8 \%$ in the compound feed. 


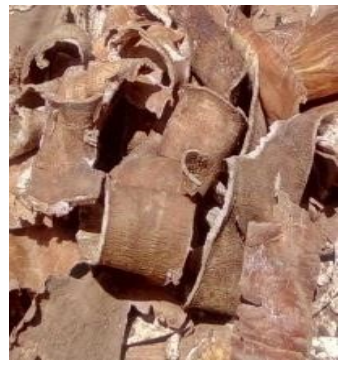

(a)

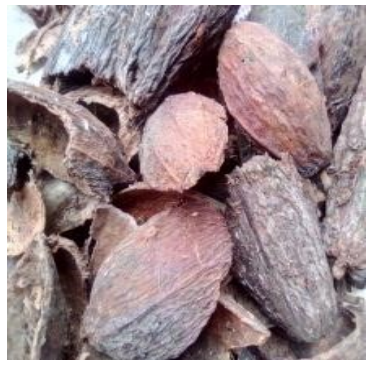

(b)

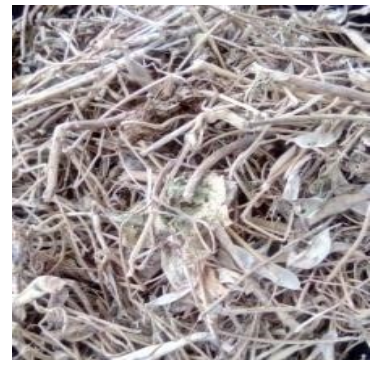

(c)

Figure 1. Cassava peelings (a); cocoa pod husks (b); bean tops (c).

\subsection{Experimental Rations}

The ration was formulated according to the nutritional requirements of the cavy, and the ingredients were purchased from dealers of agricultural by-products. A single feed was composed with these ingredients (Table 1) and to this feed was added $0.8 \%$ of biochar powder as a feed additive to make the different experimental rations. The different rations were then pelleted before being fed to the animals.

The daily pelleted ration served was $0.15 \mathrm{~g} / \mathrm{g}$ PV for each treatment consisting of the following:

- T: basal diet without charcoal (control);

- EM: basal diet containing $0.8 \%$ cassava peelings charcoal powder;

- CC: basal diet containing $0.8 \%$ charcoal powder of cocoa pod husks;

- FH: basal diet containing $0.8 \%$ charcoal powder of bean tops.

\subsection{Evaluation of the Mineral Composition of Biochar}

The powder of each biochar (100 g) was collected and analyzed at the laboratory of Environmental Analysis of the University of Laval-Quebec for the determination of the mineral composition following the procedure described by AOAC [14].

\subsection{Evaluation of the Effects of the Different Biochar Powders in the Ration on the Reproductive Performance of the Cavy}

A digestibility test was previously carried out with six organic charcoals (plantain peelings, cassava peelings, cocoa pod husks, coconut husks, maize cobs and bean tops) compared to the basal diet. Three charcoals (cassava peelings, cocoa pod husks and bean tops) were selected for this trial. Ninety-six (96) adult cavies were placed in a completely randomized design. At the beginning of the trial, the number of breeding females as well as their fasting weight was recorded and these females were distributed homogeneously in each pen where they followed several successive stages: mating-gestation-parturition-lactation-weaning of the young. During gestation, the number of females that aborted was recorded. The number of females that gave birth and the date of parturition were then recorded. At birth, the number of stillborn and live-born kids was recorded. 
Table 1. Centesimal composition of the feed.

\begin{tabular}{|c|c|}
\hline Ingredients & Quantities (kg) \\
\hline Corn & 30 \\
\hline Cassava & 04 \\
\hline Pellets & 12 \\
\hline Pennisetum purpureum & 13 \\
\hline Soybean cake & 04 \\
\hline Cotton cake & 08 \\
\hline Palm kernel cake & 14 \\
\hline Fish meal & 09 \\
\hline Bone meal & 01 \\
\hline shellfish & 01 \\
\hline Concentrate $10 \%$ * & 02 \\
\hline Molasses & 02 \\
\hline Total & 100 \\
\hline \multicolumn{2}{|c|}{ Chemical composition } \\
\hline Dry matter (\%) & 94 \\
\hline Organic matter (\% DM) & 89.2 \\
\hline Crude protein (\% DM) & 17.7 \\
\hline Fat (\% DM) & 2.99 \\
\hline Crude cellulose (\% DM) & 14.46 \\
\hline Ash (\% DM) & 10.80 \\
\hline Digestible energy (kcal/kg DM) & 2900.46 \\
\hline
\end{tabular}

*The analytical calculation of the $10 \%$ concentrate used shows $40 \%$ crude protein, $3 \%$ lysine, $1.7 \%$ methionine, $7 \%$ calcium, $1.8 \%$ phosphorus and $2100 \mathrm{kcal} / \mathrm{kg}$ metabolizable energy.

Then, the number of dead kids before weaning and the number of weaned kids were also recorded. The amount of feed served (between 7:00 and 9:00 am) was maintained in pregnant and lactating pigs until weaning (21 days after birth).

The following reproductive parameters were evaluated:

- Fertility or parturition rate $=($ females with mid-calf $) /($ females mated $) \times 100$;

- Fecundity rate $=($ stillbirths + live births $) /($ females bred $) \times 100$;

- Net fecundity rate $=($ live-born young $) /($ females bred $) \times 100$;

- Litter size = (pups born) $/($ females in mid-calf);

- Viability at birth $=$ (live births) $/$ (live births) $\times 100$;

- Weaning viability or weaning rate $=($ weaned $) /($ live-born $) \times 100$;

- Pre-weaning mortality rate $=($ kids dead before weaning $) /($ kids born alive $)$ 
$\times 100$.

\subsection{Evaluation of the Effects of Different Biochar Powders in the Diet on the Pre-Weaning Growth Performance of Cavy}

At birth, each newborn was identified with numbered loops attached to the ear. Furthermore, at farrowing, the dams were weighed as well as their young. Also, during this breeding period, the weights of breeding females, during lactation and of the pups after birth were recorded weekly. These data were used to determine feed intake, weekly weight change, total weight gain (TG) (g) and average daily gain (ADG)

\subsection{Statistical Analysis}

Data were subjected to one-way analysis of variance (ANOVA) following the general linear model (GLM). When significant differences existed between treatments, the means were separated by the Waller Duncan test at the $5 \%$ significance level [15]. The SPSS 26.0 analysis software was used.

\section{Results}

\subsection{Mineral Composition of the Different Biochar}

The mineral composition of the different biochar produced shows that it varies with the nature of the substrate (Table 2). The bean husk charcoal has the highest ash content (26\%), while the lowest content is that of cocoa pods. Regarding macro-elements, $\mathrm{Ca}, \mathrm{K}$ and $\mathrm{P}$ concentration was higher with bean husk biochar, and $\mathrm{Na}$ concentration was higher in cassava peel biochar. Cocoa pod shell biochar showed the highest $\mathrm{Mg}$ concentration. For trace elements, the concentration of $\mathrm{Cd}, \mathrm{Cr}, \mathrm{Fe}, \mathrm{Pb}$ and $\mathrm{Se}$ was higher with cassava peel biochar, and that of $\mathrm{B}$, $\mathrm{Cu}, \mathrm{Ni}$ and $\mathrm{Zn}$ was higher in cocoa pod shell biochar. The bean husk biochar had the highest concentration of Mo.

\subsection{Effects of Different Biochar Powders on Reproductive Performance}

The average reproductive performances of females according to the type of charcoal included in the ration revealed (Table 3) that females receiving the rations containing the different biochar showed (except for fertility rate), the lowest fertility rates, net fertility rate, viability at birth compared to the control. Similarly, the abortion rate was very high $(>50 \%)$ in females receiving the ration containing the biochar.

\subsection{Effects of Different Biochar Powders on Growth Performance in Cavy}

\subsubsection{Feed Intake in Female Breeders}

The inclusion of the different biochar at $0.8 \%$ in the pelleted feed had no significant effect $(p>0.05)$ on the ingestions of dry matter, organic matter, crude protein and crude cellulose in female breeders (Table 4). 
Table 2. Mineral composition of biochar.

\begin{tabular}{|c|c|c|c|}
\hline Chemical properties & $\begin{array}{c}\text { Cocoa pods husks } \\
\text { (CC) }\end{array}$ & $\begin{array}{l}\text { Bean tops } \\
\quad(\mathrm{FH})\end{array}$ & $\begin{array}{c}\text { Cassava peelings } \\
\text { (EM) }\end{array}$ \\
\hline Water retention capacity $(\mathrm{g} / \mathrm{g})$ & 1.072 & 1.042 & 1.269 \\
\hline$\%$ ash & 20 & 26 & 24 \\
\hline Total nitrogen (\%) & 0.92 & 1.65 & 1.1 \\
\hline Total carbon (\%) & 62.51 & 61.83 & 63.06 \\
\hline \multirow[t]{2}{*}{$\mathrm{C} / \mathrm{N}$} & 67.95 & 37.45 & 55.07 \\
\hline & \multicolumn{3}{|l|}{ Macro-elements } \\
\hline Na concentration $(\mathrm{cmol}(+) / \mathrm{kg})$ & 20.11 & 37.54 & 130.80 \\
\hline Ca concentration $(\mathrm{cmol}(+) / \mathrm{kg})$ & 311.98 & 1004.76 & 354.90 \\
\hline Mg concentration $(\mathrm{cmol}(+) / \mathrm{kg})$ & 873.14 & 820.51 & 146.22 \\
\hline K concentration $(\mathrm{cmol}(+) / \mathrm{kg})$ & 5950.14 & 6289.16 & 2527.85 \\
\hline Soufre (\%) & 0.10 & 0.07 & 0.16 \\
\hline \multirow[t]{2}{*}{ Total phosphorus (mg P/kg) } & $54,573.91$ & 86421.9 & $57,524.56$ \\
\hline & \multicolumn{3}{|l|}{ Trace elements } \\
\hline B concentration (mg B/kg) & 1229.66 & 997.42 & 559.57 \\
\hline Cd concentration $(\mathrm{mg} \mathrm{Cd} / \mathrm{kg})$ & 3.78 & 5.94 & 17.69 \\
\hline Cr concentration (mg Cr/kg) & 5.40 & 26.35 & 61.29 \\
\hline $\mathrm{Cu}$ concentration $(\mathrm{mg} \mathrm{Cu} / \mathrm{kg})$ & 829.87 & 629.97 & 495.23 \\
\hline Fe concentration (mg Fe/kg) & 4280.36 & $53,668.43$ & $172,115.11$ \\
\hline Mo concentration (mg Mo/kg) & 11.70 & 288.03 & 139.95 \\
\hline Ni concentration (mg Ni/kg) & 397.29 & 46.89 & 122.38 \\
\hline $\mathrm{Pb}$ concentration $(\mathrm{mg} \mathrm{Pb} / \mathrm{kg})$ & 51.77 & 86.58 & 206.39 \\
\hline Se concentration (mg Se/kg) & 4.99 & 28.77 & 53.21 \\
\hline $\mathrm{Zn}$ concentration $(\mathrm{mg} \mathrm{Zn} / \mathrm{kg}$ ) & 987.43 & 612.54 & 695.41 \\
\hline
\end{tabular}

Table 3. Average reproductive performance in cavy according to the different rations.

\begin{tabular}{ccccc}
\hline \multirow{2}{*}{ Characteristics } & \multicolumn{4}{c}{ Treatments } \\
\cline { 2 - 5 } & T & EM & CC & FH \\
\hline Fertility rate (\%) & 82.35 & 83.33 & 87.5 & 84.2 \\
Litter size & 1 & 1 & 1 & 1 \\
Fecundity rate (\%) & 70.59 & 44.44 & 43.75 & 42.11 \\
Net fecundity rate (\%) & 88.23 & 33.33 & 25.00 & 21.05 \\
Viability at birth (\%) & 100 & 75.00 & 57.14 & 50.00 \\
Viability at weaning (\%) & 100 & 100 & 100 & 100 \\
Abortion rate (\%) & 11.76 & 50.00 & 62.50 & 63.16 \\
Pre-weaning mortality rate (\%) & 0 & 0 & 0 & 0 \\
\hline
\end{tabular}


Table 4. Feed intake in cavy during gestation according to different rations.

\begin{tabular}{cccccccc}
\hline Ingestions & \multicolumn{9}{c}{ Treatments } & \multirow{2}{*}{ SEM } & p & CV \\
\cline { 2 - 6 } (g DM/d/animal) & T & EM & CC & FH & & & \\
\hline Dry matter (DM) & 28.94 & 28.48 & 30.49 & 29.05 & 0.730 & 0.800 & 15.79 \\
Organic matter (OM) & 25.81 & 25.40 & 27.19 & 25.91 & 0.651 & 0.800 & 15.79 \\
Crude protein (CP) & 4.06 & 3.99 & 4.27 & 4.07 & 0.102 & 0.800 & 15.79 \\
Crude cellulose (CC) & 4.66 & 4.59 & 4.91 & 4.68 & 0.117 & 0.800 & 15.79 \\
\hline
\end{tabular}

SEM: Standard Error on the Mean; p: Probability; CV: Coefficient of Variation; T: Feed without charcoal (control); EM: Feed containing 0.8 charcoal based on cassava peelings; CC: Feed containing 0.8 charcoal based on cocoa pod husks; FH: Feed containing 0.8 charcoal based on bean hulls.

\subsubsection{Variation in Weight of Lactating Females}

The variation in the average weight of lactating females during the lactation period shows that, overall, the percentage of weight loss of animals fed the charcoal-containing diet remained low compared to that of animals fed the control ration (Figure 2). In fact, lactating cows receiving the EM ration recorded a weight gain of $0.91 \%$; the CC ration, a loss of $9.87 \%$; the $\mathrm{FH}$ ration, a loss of $1.49 \%$ and the control ration a loss of $21.71 \%$.

\subsubsection{Weight Variation of Pre-Weaned Kids}

The variation in the weight of the kids from birth to weaning, according to the rations (Figure 3 ) shows that, at birth and at weaning, the animals receiving the FH ration had the highest average weight (96 g and $197.25 \mathrm{~g}$ ). The animals receiving the $0.8 \%$ cassava peel charcoal (EM) ration had the lowest average weight $(79.83 \mathrm{~g})$ at birth, while at weaning the lowest average weight $(137.7 \mathrm{~g})$ was recorded with the animals receiving the control ration $(\mathrm{T})$. The animals receiving the FH ration had the highest weight gain $(105.47 \%)$, followed by the animals receiving the EM ration (102.92\%), then the animals receiving the CC ration (74\%) and finally those receiving the control ration (52.49\%).

Overall, we note that the animals receiving the feed containing organic charcoal showed the best results, especially those receiving charcoal made from bean tops.

The weight evolution of kids from birth to weaning according to the feed rations reveals that at birth, the different rations had no significant $(p>0.05)$ effect on piglet weights (Table 5).

At weaning, the weights of animals receiving the control, EM, and CC rations were comparable and significantly lower than those receiving the $\mathrm{FH}$ ration.

The TG and ADG of the animals receiving the rations containing the biochar were significantly higher than the control, and the FH ration had the highest TG and ADG $(\mathrm{p}<0.05)$.

\section{Discussion}

For this study, the organic biomasses used to make the different biochar are of 


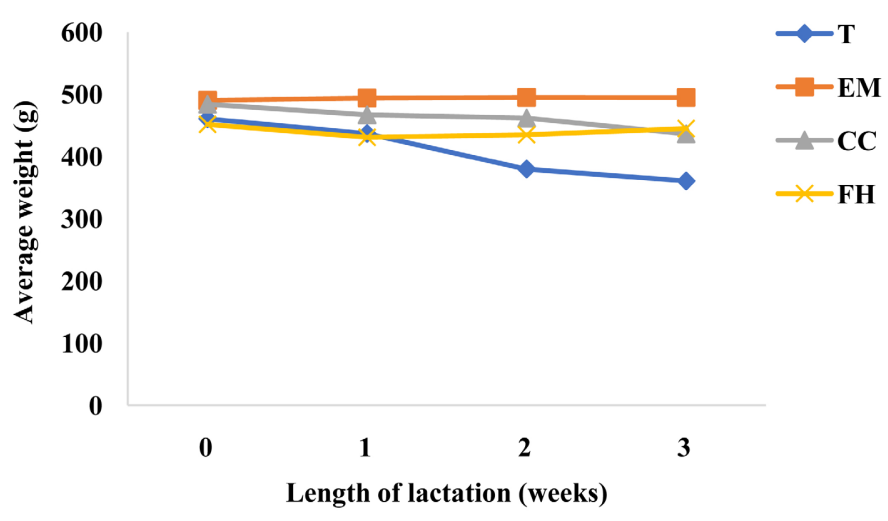

Figure 2. Variation in average weight of lactating females from farrowing to weaning, according to feed rations.

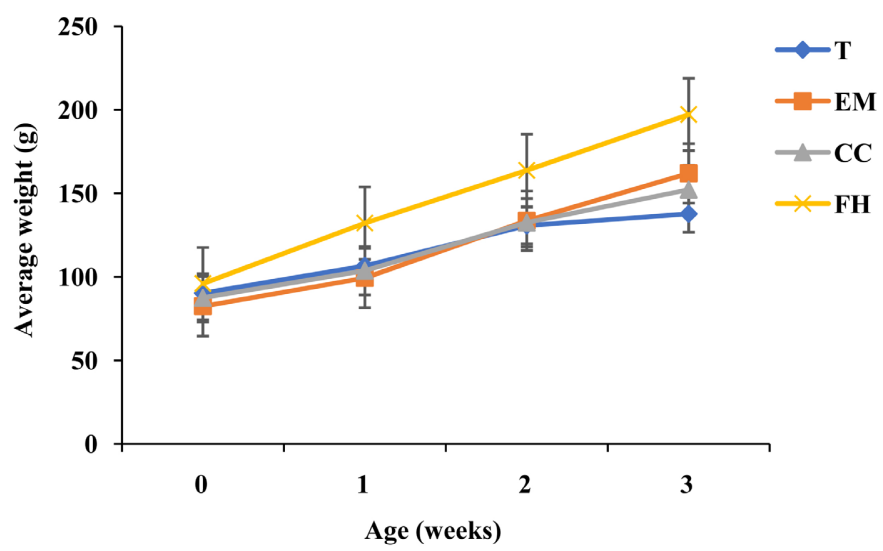

Figure 3. Variation in piglet weight from birth to weaning, according to rations.

Table 5. Weight evolution of kids from birth to weaning according to feed rations.

\begin{tabular}{ccccccccc}
\hline \multirow{2}{*}{ Characteristics } & \multicolumn{5}{c}{ Treatments } & \multirow{2}{*}{ SEM } & p & CV \\
\cline { 2 - 7 } & T (12) & EM (6) & CC (4) & FH (4) & & & \\
\hline Birth weight (g) & $90.30^{\mathrm{a}}$ & $79.83^{\mathrm{a}}$ & $87.50^{\mathrm{a}}$ & $96.00^{\mathrm{a}}$ & 3.292 & 0.460 & 18.29 \\
Weaning weight (g) & $137.70^{\mathrm{b}}$ & $162.00^{\mathrm{b}}$ & $152.25^{\mathrm{b}}$ & $197.25^{\mathrm{a}}$ & 5.829 & 0.001 & 18.28 \\
Total gains (g) & $47.40^{\mathrm{d}}$ & $82.17^{\mathrm{b}}$ & $64.75^{\mathrm{c}}$ & $101.25^{\mathrm{a}}$ & 4.940 & 0.000 & 15.45 \\
ADG (g/j) & $2.25^{\mathrm{d}}$ & $3.91^{\mathrm{b}}$ & $3.085^{\mathrm{c}}$ & $4.82^{\mathrm{a}}$ & 0.235 & 0.000 & 35.59
\end{tabular}

a; b; c; d: Means with the same letters on the same line are not significantly different at the 5\% level; ADG: Average daily gain; SEM: Standard error of the mean; P: Probability, CV: Coefficient of variation; ( ): Number of kids.

plant origin (cassava peelings, cocoa pod husks and bean tops) and rich in carbon. In Cameroon, these residues are buried in the soil as an amendment or burned, resulting in environmental pollution [16]. However, in agronomy, these residues would present more advantages when used as biochar. Feedstock, temperature, temperature rise rate, and particle size can affect the physicochemical properties and quality of biochar [17]. However, biochar is predominantly com- 
posed of carbon, hydrogen, nitrogen-oxygen, and sulfur [13]. Besides $\mathrm{C}, \mathrm{H}, \mathrm{O}$, $\mathrm{N}$, and $\mathrm{S}$, mineral elements are also present on the surfaces of biochar [7]. The high mineral concentration in bean tops charcoal is thought to be related to the high ash content in the charcoal. Indeed, Zama et al. [7] report that, increasing the ash content of coals favors increasing the concentration of $\mathrm{Mg}, \mathrm{Ca}, \mathrm{K}$ and $\mathrm{P}$. which is in agreement with our results.

Regardless of the reproductive parameter studied, females receiving the control ration showed the best rates, (except for fertility rate, litter size, viability at weaning and pre-weaning mortality rate which are comparable between treatments) compared to the other treatments. Abortion rates of $50 \% ; 62.50 \%$ and 63.16\% respectively of EM; CC and FH charcoals were recorded. This rate remained very high compared to the $11.76 \%$ observed at the control ration. This high abortion rate could be explained by the fact that carbons generally have a high specific surface area which gives them a high adsorption capacity (A). This could also be related to the very high phosphorus level on the surface of biochar, which could affect the absorption of certain minerals. As demonstrated by Guivier (1974), quoted by Boussarie [18], an excess of phosphorus is very damaging because it increases the need for $\mathrm{Mg}, \mathrm{Ca}, \mathrm{K}$ by reducing their intestinal absorption by $50 \%$. Overall, excess phosphorus in the diet is more harmful to the guinea pig than excess calcium, which is relatively well tolerated. It should also be noted that calcium deficiency at the end of gestation can result in difficult births and dystocia. Hence, the birth of unsustainable kids and very weak females those sometimes die a few days after giving birth. The highest abortion rate with the FH ration would be due to the high level of macro-elements (calcium, potassium and phosphorus) in the bean charcoal. These macronutrients could interfere with the absorption of trace elements such as copper, iodine, manganese, selenium and zinc, which have an important impact on reproduction [19] and whose deficiency causes abortion [20]. Females receiving rations containing $0.8 \%$ charcoal (EM, CC and $\mathrm{FH}$ ) had the lowest fecundity (44.44\%, $43.75 \%$ and $42.11 \%)$ and net fecundity (33.33\%, 25\% and $21.05 \%)$. This would be related to the high rate of abortions recorded with these rations, which thus reduce the number of pups at farrowing. Therefore, the viability rate will be affected, as this rate is related to the number of viable pups at birth. Feed intake was comparable between the different treatments. These results are contrary to those obtained by Mekbungwan et al. [21] who reported that biochar would significantly increase feed intake in kids when incorporated into the ration. On the other hand, the work of Kana et al. [10] showed that biochar significantly decreased feed intake in poultry when incorporated into the ration. This difference would be explained by the fact that feed intake varies by animal species.

From farrowing to weaning, a low percentage of weight loss was recorded in lactating females fed a diet containing biochar. Since one of the particularities of cavy is the suckling of their offspring, this low weight loss would be related to the number of lactating animals. This is because milk secretion could continue after abortion. In contrast to the lactating females on the charcoal diet, those on 
the control diet showed a significant weight loss. This could be explained by the fact that during lactation, dams expend a lot of energy for milk production [22]. In addition, the female has to make a lot of effort to cover the demand of the young [23]. She must therefore mobilize her body reserves to ensure satisfactory milk production, which would explain the observed weight loss. However, the slight weight gain in lactating females fed the EM diet could be explained by the presence of the more concentrated trace elements in this charcoal: iron $(172,115.11$ $\mathrm{mg} / \mathrm{kg}$ ) which is essential for the production of adenosine triphosphate (ATP), the primary source of body energy; and selenium $(53.21 \mathrm{mg} / \mathrm{kg}$ ) which is necessary for growth, fertility and the prevention of various diseases [9]. In this study, the average birth weights of the kids were comparable to each other. At weaning, the incorporation of biochar in the feed improved the weight gain of the kids. This is thought to be due to the fact that biochar increases digestion of the feed while providing a habitat for the gut microbiota to become more efficient [12]. The highest average weight $(197.25 \pm 46.9 \mathrm{~g})$ obtained with the FH ration is thought to be related to the macronutrients involved in the microbial fermentations of the cecal flora. Thus, phosphorus and magnesium would be used by the caecal microbes for cellulose digestion and microbial protein synthesis [19]. This results in increased nutrients from the coprophagic process in the guinea pig [18]. Like the ruminant, the proper inclusion of calcium in the ration is imperative for proper physiological function and growth of cavy [24].

\section{Conclusion}

At the end of this study, it appears that:

- The mineral composition of biochar varies with the nature of the substrate;

- The supplementation of biochar as a feed additive $(0.8 \%)$ in the guinea pig feed is detrimental to reproduction;

- Cassava peelings biochar is better for postpartum growth in cavy while bean tops biochar shows the best results for kid growth.

\section{Conflicts of Interest}

The authors declare no conflicts of interest regarding the publication of this paper.

\section{References}

[1] Metre, T.K. (2012) Possibilités d'amélioration de l'élevage de cobaye (Cavia porcellus L.) au Sud Kivu, à l'Est de la République Démocratique du Congo. Mémoire présenté en un diplôme de Master complémentaire en gestion des ressources animales et végétales en milieux tropicaux. Université de Liège, Académie Universitaire WollonieEurope. $52 \mathrm{p}$.

[2] Noumbissi, M.N.B., Tendonkeng, F., Zougou, T.G., Miégoué, E., Lemoufouet, J., Boukila, B. and Pamo, T.E. (2013) Effet de la complémentation au Tithonia diversifolia sur l'évolution du poids post-partum et la croissance pré-sevrage des cobayes (Cavia porcellus L.). Livestock Research for Rural Development, 25, Article No. 145. http://www.lrrd.org/lrrd25/8/noum25145.htm 
[3] Miégoué, E., Tendonkeng, F., Lemoufouet, J., Noumbissi, M.N.B., Mweugang, N.N., Zougou, T.G., Nkouadjio, M.F., Boukila, B. and Pamo, T.E. (2016) Croissance pré-sevrage des cobayes nourris au Panicum maximum supplémenté avec une ration contenant Arachis glabrata, Calliandra calothyrsus ou Desmodium intortum. International Journal of Biological and Chemical Sciences, 10, 313-325.

http://www.ifg-dg.org

https://doi.org/10.4314/ijbcs.v10i1.24

[4] MINEPIA (2009) Schéma directeur pour le développement des filières de l'élevage au Cameroun Volume II: Cartographie des filières. 211-228.

[5] Niba, A.T., Meutchieye, F., Fon, D., Laisin, A.G., Taboh, H., Njakoi, H., Bela Tomo, A., Maass, B.L., Djikeng, A. and Manjeli, Y. (2012) Current Situation of Cavy Production in Cameroon: Challenges and Opportunities. Livestock Research for Rural Development, 24, Article No. 194.

http://www.lrrd.org/lrrd24/11/niba24194.htm

[6] Defang, H.F., Keambou, T.C., Manjeli, Y., Teguia, A. and Pamo, T.E. (2014) Influence de la farine des feuilles de Leucaena leucocephala sur les performances de croissance des lapereaux. International Journal of Biological and Chemical Sciences, 8, 1430-1437. https://doi.org/10.4314/ijbcs.v8i4.7

[7] Zama, E.F., Zhu, Y.-G. and Reid, B.J. (2017) The Role of Biochar Properties in Influencing the Sorption and Desorption of $\mathrm{Pb}(\mathrm{II}), \mathrm{Cd}(\mathrm{II})$ and $\mathrm{As}(\mathrm{III})$ in Aqueous Solution. Journal of Cleaner Production, 148, 127-136.

https://doi.org/10.1016/j.jclepro.2017.01.125

[8] Kolodziej, A. and Jacyno, E. (2005) Effect of Selenium and Vitamin E Supplementation on Reproductive Performance of Young Boars. Archiv fur Tierzucht, 48, 68-75. https://doi.org/10.5194/aab-48-68-2005

[9] Krsk, P., Lahucky, R., Küchenmeister, U., Nürnberg, K., Palanska, O., Bahelka, I., Kuhn, G. and Ender, K. (2001) Effect of Dietary Organic Selenium and Vitamin E Supplementation on Post Mortem Oxidative Deterioration in Muscles of Pigs. Archiv fur Tierzucht, 44, 193-201. https://doi.org/10.5194/aab-44-193-2001

[10] Kana, J.R., Fulefack, H.D., Teguia, A., Tchegne, B.D.T., Kana, Y. and Mongo, B. (2012) Effet activateur de croissance du charbon de noyaux de Canarium schweinfurthii Engl en substitution de l'antibiotique dans l'aliment du poulet de chair. Livestock Research for Rural Development, 24, Article No. 131. http://www.lrrd.org/lrrd24/8/kana24131.htm

[11] Prasai, T.P., Walsh, K.B., Midmore, D.J. and Bhattarai, S.P. (2017) Effect of Biochar, Zeolite and Bentonite Feed Supplements on Egg Yield and Excreta Attributes. Animal Production Science, 58, 1632-1641. https://doi.org/10.1071/AN16290

[12] Leng, R.A., Preston, T.R. and Inthapanya, S. (2012) Biochar Reduces Enteric Methane and Improves Growth and Feed Conversion in Local "Yellow" Cattle Fed Cassava Root Chips and Fresh Cassava Foliage. Livestock Research for Rural Development, 24, Article No. 199. http://www.lrrd.org/lrrd24/11/leng24199.htm

[13] Thuy Hang, L.T., Preston, T.R., Ba, N.X. and Dung, D.V. (2019) Effect of Biochar on Growth and Methane Emissions of Goats Fed Fresh Cassava Foliage. Livestock Research for Rural Development, 31, Article No. 67. http://www.lrrd.org/lrrd31/5/thuyhang31067.html

[14] A.O.A.C. (2000) Association of Official Analytical Chemists International (AOAC) Official Methods of Analysis. 17th Edition, AOAC International, Washington DC.

[15] Steel, R.G. and Torrie, J.H. (1980) Principles and Procedures of Statistics. McGraw Hill Book, New York, 633 p. 
[16] Tendonkeng, F., Miegoue, E., Lemoufouet, J., Fogang, Z.B. and Pamo, T.E. (2018) Rice Straw Production and Potential Uses in Cameroon. In: Timayer, A. and Kadyrov, G., Eds., Rice and Rice Straw: Production, Cultivation and Uses, Nova Science Publishers, Inc., Hauppauge, 1-53.

[17] Brewer, C.E., Chuang, V.J., Masiello, C.A., Gonnermann, H., Gao, X., Dugan, B., Driver, L.E., Panzacchi, P., Zygourakis, K. and Davies, C. (2014) New Approaches to Measuring Biochar Density and Porosity. Biomass and Bioenergy, 66, 176-185. https://doi.org/10.1016/j.biombioe.2014.03.059

[18] Boussarie, D. (2000) Le cobaye, milieu de vie et alimentation. Le nouveau praticien vétérinaire, 2, 65-67.

[19] Hostetler, C.E., Kincaid, R.L. and Mirando, M.A. (2003) The Role of Essential Trace Elements in Embryonic and Fetal Development in Livestock. The Veterinary Journal, 166, 125-139. https://doi.org/10.1016/S1090-0233(02)00310-6

[20] Brisson, J., Lefebvre, D., Gosselin, B., Petit, H. and Evans, E. (2003) Nutrition, alimentation et reproduction. In: Symposium sur les bovins laitiers, CRAAQ Centre de références en agriculture et agroalimentaire de Quebec, Saint-Hyacinthe, 66 p.

[21] Mekbungwan, A., Yamauchi, K. and Sakaida, T. (2004) Intestinal Villus Histological Alterations in Piglets Fed Dietary Charcoal Powder Including Wood Vinegar Compound Liquid. Anatomia, Histologia, Embryologia, 33, 11-16. https://doi.org/10.1111/j.1439-0264.2004.00501.x

[22] Michel, C.L. and Bonnet, X. (2012) Influence of Body Condition on Reproductive Output in the Guinea Pig. Journal of Experimental Zoology, 317, 24-31. https://doi.org/10.1002/jez.714

[23] Laurien-Kehnen, C. and Trillmich, F. (2003) Lactation Performance of Guinea Pigs (Cavia porcellus) Does Not Respond to Experimental Manipulation of Pup Demands. Behavioral Ecology and Sociobiology, 53, 145-152. https://doi.org/10.1007/s00265-002-0550-7

[24] Stein, H.H., Adeola, O., Cromwell, G.L., Kim, S.W., Mahan, D.C. and Miller, P.S. (2011) Concentration of Dietary Calcium Supplied by Calcium Carbonate Does Not Affect the Apparent Total Tract Digestibility of Calcium, But Decreases Digestibility of Phosphorus by Growing Pigs. Journal of Animal Science, 89, 2139-2144. https://doi.org/10.2527/jas.2010-3522 